Bangladesh J. Bot. 43(2): 213-217, 2014 (September)

\title{
ANTAGONISTIC POTENTIAL OF RHIZOSPHERE FUNGI AGAINST LEAF SPOT AND FRUIT ROT PATHOGENS OF BRINJAL
}

\author{
MT AKTAR, KS HOSSAIN ${ }^{1}$ AND MA BASHAR* \\ Department of Botany, University of Dhaka, Dhaka-1000, Bangladesh
}

Key words: Antagonist, Aspergillus, Brinjal, Penicillium, Trichoderma, Volatile metabolites

\begin{abstract}
Antagonistic potentials of seven rhizoshere soil fungi viz., Aspergillus flavus Link., A. fumigatus Fresen., A. niger Tiegh., A. terreus Thom., Penicillium sp., Trichoderma harzianum Refat. and T. viride Pers. were tested in opposition to six pathogenic fungi viz., Colletotrichum sp., Curvularia lunata, Fusarium moniliforme, F. oxysporum, F. semitectum and Phomopsis sp. isolated from different leaf spots and fruit rots of brinjal. Out of seven soil fungi, Trichoderma harzianum was found most effective to control the growth of all the test fungi in the study of colony interactions and effects of volatile and non-volatile metabolites. This fungus may be exploited commercially to biocontrol the diseases.
\end{abstract}

\section{Introduction}

Brinjal or eggplant (Solanum melongena L.) is an important solanaceous vegetable in Bangladesh. It is a good source of minerals and vitamins. It has several medicinal properties and more or less available round the year (Khan 1979). The crop is known to suffer from more than 70 different diseases in the world. Ten diseases have been recorded from Bangladesh. Among these leaf spots and fruit rots have significant impact on the crop yield (Ahmed and Hossain 1985).

In the recent years scientists have begun to understand the consequences of the widespread and repeated use of chemical fungicides that threaten human interest. Fungi are potentially better biocontrol agents suggesting one of the alternatives. Presently, different species of Trichoderma are used successfully to control different plant pathogens (Vinalea et al. 2008). Colony interaction between non-pathogenic and pathogenic fungi for determination of antagonism of fungi isolated from different habitats including rhizosphere are studied (Skidmore and Dickinson 1976, Bashar and Rai 1994, Brozova 2002, and Prince et al. 2011). Different rhizodeposition of plant invites beneficial microbiota around the rhizosphere. Role of rhizosphere fungi as an effective antagonist against the pathogen of the same plant is also reported (Berg et al. 2005). Many microorganisms produce biologically active volatile substances which have been noticed inhibitory or stimulatory against the growth of fungi. The production of biologically active non-volatile toxic substances by fungi has been discussed by several workers (Dennis and Webster 1971a, Skidmore and Dickinson 1976). However in Bangladesh limited studies have been done in this regard (Ahmed and Hossain 1985). Hence, the present investigation was designed to evaluate antagonistic potentiality of some rhizosphere fungi in vitro against the pathogens of leaf spots and fruit rots of brinjal.

\section{Materials and Methods}

Spotted leaves and rotten fruits of different brinjal cultivars were collected from March, 2010 to February, 2011 directly from farmers fields at Shibpur, Natore, seed production fields of BADC, Gazipur and research fields of the Botanical Garden, Dhaka University. Diseased samples were collected in separate sterile polyethylene bags, labeled properly and then brought to the

*Author for correspondence: <botanybashar@yahoo.com>. ${ }^{1}$ Department of Botany, Jagannath University, Dhaka, Bangladesh. 
laboratory for isolating associated fungi following standard blotter and agar plate methods. Among the isolated fungi Colletotrichum sp., Curvularia lunata (Wakker) Boedijn, Fusarium moniliforme Sheld., F. oxysporum Schltdl., F. semitectum Berk. \& Rav. and Phomopsis sp. were selected as test pathogens owing to their higher percentage of occurrence and previous reports as pathogenic organisms (Anonymous 1997, Richardson 1979). Fungi were isolated from rhizospheric soil of the host following serial dilution method (Brown 2004). Among the isolated soil fungi, Aspergillus flavus Link, A. fumigatus Fresen., A. niger Tiegh., A. terreus Thom., Penicillium sp., Trichoderma harzianum Refai and $T$. viride Pers. were selected to test their antagonistic potential against the pathogens following dual culture technique described by Bashar and Rai (1994). In dual culture, assessment of colony interactions grading were done based on intermingling and inhibition zone. Per cent inhibition of the growth of the test fungi due to the presence of antagonists were also calculated (Skidmore and Dickinson 1976).

Effects of volatile and non-volatile metabolites of the selected soil fungi against the test pathogens were also studied following the methods described by Dennis and Webster (1971b) and Bashar and Rai (1994), respectively.

\section{Results and Discussion}

Antagonistic potential of the selected seven soil fungi against the six test pathogens are presented in the Table 1. In this study, antagonistic relationships among the soil fungi and test pathogens ranged from grade 2 - 4 . However, grade 2 was found to be the most commonly encountered type of colony interaction as 20 interactions out of 42 were incorporated in this grade, followed by grade 3 (13 out of 42). The grade 4 was recorded infrequently (09 out of 42). Among the 7 soil fungi only Trichoderma harzianum showed grade 4 interaction against all the 6 test pathogens followed by Aspergillus niger. In accordance with the present study Prince et al. (2011) also observed interactions at grade 4 between soil fungus $T$. harzianum and sugarcane red rot pathogen Colletotrichum falcatum.

Table 1 shows that volatile substances emanating from the soil fungi inhibited radial growth of the test pathogens to varied degrees ranging $5.0-22.60 \%$. It is evident from the results that out of seven soil fungi examined, the highest inhibition was found by the volatile substance of $T$. harzianum against Phomopsis sp. followed by F. semitectum (21.50\%). The 3rd highest (20.86\%) inhibition was observed by the volatile substance of $T$. viride against $C$. lunata followed by substance of $T$. harzianum against $F$. oxysporum (20\%). Barakat et al. (2013) reported that volatile metabolites produced by an isolate of $T$. harzianum inhibited mycelial growth of Botrytis fabae by $39.77 \%$ after six days of incubation. Difference in per cent inhibition with the present study might be due to the difference in organism involved in the interaction.

The antagonistic effects owing to non-volatile metabolites of the soil fungi against the test pathogens range from 25.23 to $65.50 \%$ (Table 1). It is evident from the data presented in the table that these inhibitions of the soil fungi were much higher than those of volatile ones. The highest inhibition was observed by the culture filtrate of $T$. harzianum against $C$. lunata, followed by $F$. moniliforme (65.25\%), F. oxysporum (63.50\%) and Colletotrichum sp. (62.50\%). The inhibition of the radial growth of the test fungi due to non-volatile metabolites, may be attributed to the production of antibiotic substances in the culture filtrates and impoverishment of nutrient (Kexiang et al. 2002, Howell 2003, Wool and Larito 2007). It has also been reported that the antibiotic production varies depending on the comparing organisms. Differential sensitivity of the pathogen to the staling growth products of the fungi was also observed. This may be due to the genetic potentialities of the pathogen to tolerate a particular antibiotic substance and the chemical 
properties of the staling substances. The environmental parameters, nutrients, media and the assay method also influences the antifungal activity of a fungus (Fravel 1988, Prince et al. 2011).

Table 1. Antagonistic potential of rhizophere fungi against leaf spots and fruit rots pathogens of brinjal.

\begin{tabular}{|c|c|c|c|c|c|c|}
\hline \multirow{2}{*}{$\begin{array}{l}\text { Name of } \\
\text { soil fungi }\end{array}$} & \multicolumn{6}{|c|}{ Test pathogens } \\
\hline & Co & $\mathrm{Cu}$ & $\mathrm{Fm}$ & Fo & Fs & $\mathrm{Ph}$ \\
\hline \multicolumn{7}{|c|}{ Grades in colony interactions } \\
\hline Aspergillus flavus & 2 & 2 & 3 & 3 & 2 & 2 \\
\hline A. fumigatus & 2 & 2 & 2 & 2 & 2 & 2 \\
\hline A. niger & 3 & 4 & 4 & 3 & 2 & 3 \\
\hline A. terreus & 2 & 2 & 2 & 2 & 2 & 2 \\
\hline Penicillium sp. & 3 & 3 & 3 & 3 & 2 & 3 \\
\hline Trichoderma harzianum & 4 & 4 & 4 & 4 & 4 & 4 \\
\hline T. viride & 2 & 3 & 4 & 2 & 3 & 3 \\
\hline \multicolumn{7}{|c|}{ Per cent inhibition by volatile substances: } \\
\hline Aspergillus flavus & 11.78 & 10.50 & 8.25 & 18.00 & 8.00 & 10.50 \\
\hline A. fumigatus & 11.00 & 7.90 & 7.50 & 12.00 & 7.75 & 9.50 \\
\hline A. niger & 14.68 & 14.85 & 15.50 & 14.50 & 9.50 & 18.70 \\
\hline A. terreus & 8.50 & 5.25 & 6.00 & 7.57 & 5.00 & 5.50 \\
\hline Penicillium sp. & 12.45 & 14.78 & 10.25 & 16.00 & 9.45 & 19.25 \\
\hline Trichoderma harzianum & 15.50 & 16.86 & 17.50 & 20.00 & 21.50 & 22.60 \\
\hline T. viride & 11.00 & 20.86 & 15.00 & 10.25 & 13.50 & 15.65 \\
\hline \multicolumn{7}{|c|}{ Per cent inhibition by non-volatile metabolites: } \\
\hline Aspergillus flavus & 40.00 & 40.32 & 48.20 & 45.75 & 40.00 & 33.45 \\
\hline A. fumigatus & 37.20 & 28.51 & 40.00 & 39.00 & 28.50 & 29.10 \\
\hline A. niger & 52.56 & 52.50 & 60.50 & 52.00 & 45.00 & 45.03 \\
\hline A. terreus & 30.50 & 30.50 & 30.50 & 30.50 & 30.50 & 30.50 \\
\hline Penicillium sp. & 42.00 & 60.25 & 53.40 & 50.50 & 43.50 & 40.52 \\
\hline Trichoderma harzianum & 62.50 & 65.50 & 65.25 & 63.50 & 55.00 & 50.84 \\
\hline T. viride & 44.72 & 60.07 & 60.25 & 58.25 & 50.00 & 35.22 \\
\hline \multicolumn{7}{|c|}{ Per cent inhibition in colony interaction: } \\
\hline Aspergillus flavus & 54.19 & 51.78 & 66.66 & 65.62 & 47.36 & 46.03 \\
\hline A. fumigatus & 50.25 & 45.52 & 50.00 & 51.50 & 46.15 & 41.47 \\
\hline A. niger & 68.66 & 75.87 & 80.35 & 55.74 & 50.70 & 65.85 \\
\hline A. terreus & 40.00 & 40.00 & 40.00 & 42.66 & 39.52 & 35.50 \\
\hline Penicillium sp. & 56.25 & 76.53 & 67.62 & 65.25 & 50.00 & 63.23 \\
\hline Trichoderma harzianum & 76.95 & 80.00 & 81.48 & 76.63 & 72.90 & 72.89 \\
\hline T. viride & 57.24 & 75.50 & 80.26 & 55.35 & 56.52 & 53.58 \\
\hline
\end{tabular}

$\mathrm{Co}=$ Colletotrichum sp., $\mathrm{Cu}=$ Curvularia lunata, $\mathrm{Fo}=$ Fusarium oxysporum, $\mathrm{Fs}=F$. semitectum, $\mathrm{Fm}=$ F. moniliforme and $\mathrm{Ph}=$ Phomopsis sp.. Grades from 1 (mutually intermingling growth) to 5 (mutual inhibition at a distance), as proposed by Skidmore and Dickinson (1976) are as follows: Grade $1=$ Mutual intermingling without any macroscopic sights of interaction. Grade 2 = Mutual intermingling growth where the growth of the fungus is ceased and being over growth by the opposed fungus. Grade $3=$ Intermingling growth where the fungus under observation is growing into the opposed fungus either above (or) below. Grade 4 = Sight inhibition of both the interacting fungi with narrow demarcation line (1 - $2 \mathrm{~mm})$. Grade $5=$ Mutual inhibition of growth at a distance of $>2 \mathrm{~mm}$. 
Results in colony interaction tests show that radial growth inhibition of the test pathogen with the soil fungi was in the range of $35.50-81.48 \%$ and the highest growth inhibition of Fusarium moniliforme was obtained by Trichoderma harzianum followed by Aspergillus niger and T. viride (Table 1). The 4th - 6th positions were $T$. harzianum against Curvularia lunata (80\%), Colletotrichum sp. (76.95\%) and F. oxysporum (76.63\%), respectively. In contrast with the present study Prince et al. (2011) reported 53.8\% inhibition of Botrytis fabae by T. harzianum in colony interaction. The less inhibition might be due to the difference in the pathogen.

Results of this experiment reveal that out of seven soil fungi examined only Trichoderma harzianum exhibited strong antagonistic effect against all the test pathogens. This effect might be due to its fast growing nature, rapid sporulation and toxin producing capacity (Skidmore and Dickinson 1976). The occurrence of inhibition zone between some of the soil fungi and the test fungi could be considered as a result of the production of secondary metabolites, antibiotics, $\mathrm{pH}$ alteration and exhaustion of nutrients and space (Chakraborty et al. 2004).

Trichoderma harzianum is known to be capable of producing antibiotics which might have suppressed the growth of the test pathogens. These results are in agreement with the findings of Adriana and Sergio (2001), Krupke et al. (2003), Kexiang et al. (2002) and Shafiquzzaman et al. (2009).

The present observation suggests that Trichoderma harzianum may be exploited commercially as a biocontrol agent of leaf spots and fruit rots of brinjal.

\section{References}

Adriana O and Sergio O 2001. In vitro evolution of Trichoderma and Gliocladium antagonism against the symbiotic fungus of the leaf-cutting ant Atta cephalotes. Mycopathol. 150 : 33-60.

Ahmed HU and Hossain MM 1985. Crop disease survey and establishment of herbarium of Bangladesh Agricultural Research Institute (BARI). Final Report (1982-85) of Plant Pathol. BARI, Joydebpur, Gazipur.

Anonymous 1997. Studies on fungal diseases of brinjal (Solanum melongena L. occurrence in Chittagong district. An MSc thesis, session: 1992-93, Department of Botany, Chittagong University, Bangladesh.

Barakat FM, Abada KA, Abou-Zeid NM and El-Gammal YHE 2013. Effect of volatile and non-volatile compounds of Trichoderma spp. on Botrytis fabae the causative agent of faba bean chocolate spot. WebPub J. Agric. Res. 1(3): 42-50.

Bashar MA and Rai B 1994. Antagonistic potential of root-region microflora of chickpea against Fusarium oxysporum f. sp. ciceri. Bangladesh J. Bot. 23(1): 13-19.

Berg RGV, Barendse GWM, Weerden GMV and Mariani C (Eds) 2005. Solanaceae V: Advances in Taxonomy and Utilization. Nijmegen, The Netherlands: Nijmegen University Press, pp. 251-274.

Brown AE 2004. Benson's Microbiological Applications: Laboratory Manual in General Microbiology. McGraw Hill, New York. pp. 432.

Brozova J 2002. Exploitation of the Mycoparasitic fungi Pythium oligandrum. Plant Protection Science 38(1):29-35.

Chakraborty MR, Dutta S, Ojha S and Chatterjee NC 2004. Antagonistic potential of biocontrol agents against Botryodiplodia theobromae causing die-back of bottle brush (Callistemon citrinus). Acta Botanica Hungarica 46 : 279-286.

Dennis C and Webster J 1971a. Antagonistic properties of species groups of Trichoderma I. Production of non-volatile antibiotics. Trans. Brit. Mycol. Soc. 57: 25-29.

Dennis, C. and J. Webster. 1971b. Antagonistic properties of species groups of Trichoderma II. Production of volatile antibiotics. Trans. Brit. Mycol. Soc. 57: 41-48.

Fravel DR 1988. Role of antibiosis in the biocontrol of plant disease. Ann. Rev. Phytopathol. 26:75-91. 
Howell CR 2003. Mechanisms employed by Trichoderma species in the biological control of plant diseases : The history and evolution of current concepts. Plant Dis. 87: 4-10.

Kexiang G, Xiaoguang L, Youghong L, Tianbo Z and Shuliang W 2002. Potential of Trichoderma harzianum and T. atroviride to control Botryosphaeria berengeriana f. sp. piricola, the cause of apple ring rot. Phytopathol. 150: 271-276.

Khan R 1979. Solanum melongena and its ancesteral forms. In: Hawkes JG, Lester RN, and Skelding AD (Eds). The Biology and Taxonomy of Solanaceae. Linnean Society Symposium, Series '7'. London (GBR): Academic Press, pp. 629-636.

Krupke, AO, Castle AJ and Rinker DL 2003. The North American mushroom competitor, Trichoderma aggressivum $f$. aggressivum, produces antifungal compounds in mushroom compost that inhibit mycelial growth of the commercial mushroom Agaricus bisporus. Mycol. Res. 107: 1467-1475.

Prince L, Raja A and Prabakaran P 2011. Antagonistic potentiality of some soil mycoflora against Colletotrichum falcatum. World Journal of Science and Technology 1(4): 39-42.

Richardson MJ 1979. An annotated list of seed-borne disease of brinjal. Sci. and Cult. 37(10) : 482-483.

Shafiquzzaman S, Yusuf UK, Hossain K and Jahan S 2009. In vitro studies on the potential Trichoderma harzianum for antagonistic properties against Ganoderma boninense. J. Food, Agri. Environ. 7 (3\&4): 970-976.

Skidmore AM and Dickinson CH 1976. Colony interaction and hyphal interference between Septoria nodorum and phylloplane fungi. Trans. Br. Mycol. Soc. 66: 57-64.

Vinalea F, Sivasithamparamb K, Ghisalbertic EL, Marraa R, Wooa SL, Loritoa M 2008. Trichoderma plant pathogen interactions. Soil Biology \& Biochemistry 40: 1-10.

Wool SL and Larito M 2007. Exploiting the interactions between fungal antagonists, pathogens and the plant for biocontrol. In: Vurro M and Gressel J (Eds.) 2007. Novel biotechnologies for biocontrol agent enhancement and management. Springer Press, Amsterdam, Netherland. pp. 425. 